\title{
MADURANESE LANGUAGE SPEECH LEVEL: A SOCIOLINGUISTIC STUDY IN LANGUAGE VARIETY
}

\author{
Eko Heriyanto $^{1}$, Didit Kurniadi ${ }^{1 *}$, Naela Hidayatul Mukaraomah ${ }^{2}$ \\ ${ }^{1}$ Language \& Culture Faculty, University of AKI, Jl. Imam Bonjol No.15-17 Semarang, Jawa Tengah, Indonesia 50173 \\ ${ }^{2}$ English Department, Universitas Negeri Semarang, Sekaran, Gunungpati, Sekaran, Kec. Gn. Pati, Kota Semarang, Jawa \\ Tengah, Indonesia 50229 \\ *didit.kurniadi@unaki.ac.id
}

\begin{abstract}
This study investigates the analysis of speech level found in Maduranese language in accordance with the study of sociolinguistics. The speech level highly correlates with language variety which becomes one of the issues in sociolinguistics study. The researcher also tried to find out the influencing factors of Maduranese speech level and language variety in it. Hence, this research belongs to qualitative research which applied descriptive qualitative method. The method of collecting data was document/literature review through particular documents that have relation with the analysis of this research. To enhance the result of analysis, the researcher also conducted interview with the native speakers of Maduranese language. The finding of this research revealed that language variety occurs in the speech level of Maduranese language. Further, there are three speech levels in Madura which has similar type with the speech level in Java such as ngoko, krama madya and krama inggil. This kind of variations are caused by its use among different social classes or status among the society.
\end{abstract}

Keywords: language variety; maduranese language; speech level

\section{INTRODUCTION}

Variation in terms of language and speakers is a variation of language that is individual and language variety of a group of individuals whose numbers are relative who inhabit a place or region. Individual language variety can be called idiolects, while language variety from a group of individuals can be called dialects. According to the idiolect concept, every individual has his/her respective idiolect. In other words, each individual has unique characteristics that are not shared by other individuals. Differences in characteristics between individuals are caused by physical and psychological factors. Physical differences, for example, are due to differences in the form of speech tools, while differences in psychological factors are usually caused by differences in temperament, character, intellectuals, and others.

Dialect is the language variety of a group of individuals who become the members of a community from particular region or social class. Dialects based on regions are called geographical dialects, while dialects based on social class are called social dialects (sociolects). In other words, regional and socioeconomic differences of speakers can cause language variety. In Chaer and Agustina (1995), Labov distinguishes language variety with respect to the level of class, status, and social class of the speakers based on: acrology, basilek, vulgarity, slang, colloquial, jargon, argot, and ken.

In terms of use, language variety are also known as language variety with regard to functions, types, or registers. Language variety in terms of usage relate to the field of use. In everyday life, for instance, there are variations in the fields of military, literature, journalism, and other scientific activities. The difference in language variety in terms of usage is in the vocabulary. Each field has a number of special vocabularies that are not in the vocabulary of other disciplines.

Hudson (1980) explains that dialects relate to language users, whereas registers relate to language use. More details, Alwasilah (in Aslinda, 2007) explains that the register is a certain variety that is used for certain purposes, as opposed to social or regional dialects. Register talks are usually 
associated with dialect problems. Dialects regard language which is used by who, where, and when. Meanwhile registers related to language problems which are used for what activities. In other words, the register can be limited more narrowly by reference to the main speech or the subject.

The choice of various languages is based on the important proposition of sociolinguistics; who is speaking, to whom, about what, when, and how meaning depends on what situation. That theory will continue to be used as long as the relationship of a language with its user community. The identification and coding of languages will be explored even more widely by the existence of intensive studies using the sociolinguistic proposition.

On this occasion, the author will examine two important things that are covered in sociolinguistic studies. Those two things are how language variety occur and how the speech level of Madura language is realized. The author chose the language of Madura because the uniqueness of Maduranese language which has both similarity and difference with Javanese language. Besides, it is hoped that this study will contribute and enrich the linguistic references of Maduranese language in Indonesia.

\section{METHOD}

Qualitative research which deals more with the framework of analysis and interpretation rather than numerical or statistical data becomes the grand design for this recent study. Further, this research applied descriptive qualitative method which gives the broad and deep explanation about the phenomena which become the research questions. This qualitative research used method of Simak Bebas Libat Cakap (SBLC) and Simak Libat Cakap (SLC) for the data collection to be analysed in Padan Method. This method can be said as informal method because it is easy to understand and it explains all variations of language which show up in the study (Rahayu, 2013).As an addtion, the researcher used document/literature review. Document/literature review dealt with particular review and analysis through documents discussing the same topic with this research. To enhance the result of analysis, the researcher also conducted interview with the native speaker of Maduranese language. Next, the collected data was analyzed using the theory of soicolinguistics particularly in the topic of language variety.

\section{RESULTS AND DISCUSSION}

What is meant by Maduranese people are those who traditionally use Maduranese language in their daily lives. As a society, Maduranese have and show a unique culture, which is different from other ethnicities. They reside on Madura Island and its surrounding islands, such as Gili Raja, Sapudi, Raas, and Kangean. Maduranese love to move to other islands. In their migration, the Maduranese migrants still use Maduranese as a tool of communication, especially for inter-ethnic communication. In Java, migrants from Madura are often found in the districts of Gresik, Surabaya, Pasuruan, Probolinggo, Bondowoso, Jember, Lumajang, and Banyuwangi. In the north coast region of East Java from Gresik to Banyuwangi the majority of the population is ethnic Maduranese.

Madura has a position as a regional language in Indonesia and it needs to be maintained (Effendy, 2011). This position is based on the fact that regional languages are an element of national culture and are protected by the government (Undang-Undang Dasar 1945, Chapter XV, Article 36). In its position, Maduranese functions as (1) a symbol of regional pride, (2) a symbol of regional identity, and (3) a tool of communication within the family and regional community. Today, at the Elementary Schools on Madura Island, whose students are Maduranese children, Maduranese is used as the language of instruction at the beginning level until third grade.

Maduranese is almost the same as Javanese. Maduranese has a variety of languages; dialectical variations and variations in speech levels. Rohaniyah (2016) explains that Maduranese has 4 different dialects, namely Bangkalan dialect, Pamekasan dialect, Sumenep dialect and Kengean dialect. Each of these dialects can be indicated from differences in word usage (lexical) and differences in pronunciation, especially with regard to prosody and intonation. 
The Bangkalan Maduranese use the Bangkalan dialect. A recognizable difference from the Bangkalan Madura dialect is the use of the word kake (you). While the Pamekasan and Sumenep dialects use the word bekna / be'en (you).

The difference in utterances in the Bangkalan dialect, for example the words jeriya (that way) and beriya (this way) are pronounced to be jriya or jirya and briya. While the other two (Sumenep and Pamekasan) say the word into jeriya and beriya. Sumenep Maduranese call star fruit as bhelimbhing, while Bangkalan Maduranese say it as bhlimbhing. The intonation of the end part of a sentence in the Maduranese Sumenep dialect tends to be longer compared to the Pamekasan and Bangkalan dialects. If the rhythm in the Sumenep dialect applies an elongated rhythm, the Madura dialect of Bangkalan applies a fast rhythm. The rhythm of pronunciation in the Bangkalan Madura language seems to be faster than the other two dialects.

In terms of pronunciation of the word, Pamekasan Maduranese commonly pronounce certain word in line with the number of its syllable such as word berempa (how) pronounced be-rem-pa. The Madura dialect in Bangkalan has experienced a reduction in pronunciation to brem-pa. The word ariya $i$ s pronounced $a-r i-y a$ not $r i-y a$. The intonation of the sentence in the Pamekasan dialect shows more ordinary rhythm.

Words like apecet [apecet] which means "massage" are only used by Maduranese Pamekasan. Maduranese outside Pamekasan use the word aorot [aorst] which also means "massage". The word jeng-ghujengan (laying on the bed) is only used by Sumenep Maduranese. Maduranese in Pamekasan and Bangkalan refer to it as dung - tedungan (laying on the bed).

Finally, the Kangean Maduranese language dialect is used by Maduranese Kangean. The difference seen is the use of the words sengkok [scyko?) or ako [ako] which means "I" and logghur which means "to fall", on other dialects using crank [əฤk ??] and gheggher [gəgghər].

\section{Speech Level in Maduranese Language}

In Madura language, there is a level of speech which consists of three levels:

1. The level of said "enjek-iye" is the kind of speech level that is equal to ngoko in the Java language that is used among peers . For example, ngakan (eating), cethak (head) and matta (eyes).

2. The "Engghi-Enten" speech level is the same type of speech level as karma madya in Javanese. For example, maddheng (eating), Serah (head), and mrepat (eye).

3. The "Engghi-Bunthen" speech level is the same level of speech as krama inggil in Javanese. For example, adhe'er (eating), mostaka (head), and Socca (eye).

Besides the three speech levels, there are speech levels divided into only two kinds, namely bhesa alos and coarse bhesa. The words maddheng, adhe'er, serah, mostaka include bhesa alos. Ngakan, abhedhuk including bhesa kasar.

In discussing the speech level, of course, it also discusses the use of the speech level. Since language is a social fact, language is also related to social class. With this social class, the use of speech level in a language is increasingly clear. However, not all languages have a speech level such as English. There are social-class dialects and social-class accents. Social class dialect refers to the grammatical differences of speakers and speech partners which are influenced by their respective backgrounds. Meanwhile, accent social class refers to phonetic and phonological differences. Most languages in Indonesia have a speech level in communication. Balinese, Javanese, Sundanese and Maduranese also have their own speech levels.

Social class refers to groups of people who have certain similarities in social fields such as economics, work, education, position, caste and so on (Sumarsono, 2010). An individual is very likely to have more than one social status. A father who works as a public school teacher can be categorized into a class of public servants who are educated. In addition, there are other social class widely known such as the employee class (employee), working class, manager class, trader class and farmer class. In 
industrialized and developing countries, it also known as lower, middle, and upper classes as the classification of the working class.

Caste is usually considered a kind of social class. When it is explored further, the two are very different. In caste people should not freely go into groups. One who is born into a Brahmin caste family is certain and must be that caste. People born from sudra caste families may not be members of the Brahmin caste. Whereas in an Industrial Country, a laborer who works diligently and actively tries in learning will be able to advance his career as a manager. In this condition, he will join the people as long as the manager. Thus, caste is closed and social class is open which allows social mobility from class to other classes.

\section{CONCLUSION}

The emergence of language variety is caused by social factors (social status, education level, age, gender, etc.) and situational factors that influence language use consisting of who speaks, in what language, to whom, when, where and about what problem. There are three (3) speech levels in Madura namely: the "enjek-iye" speech level is the same type of speech level as ngoko in Javanese that is used between peers; "Engghi-Enten" speech level is the same type of speech level as intermediate krama in Javanese; speech level "Engghi-Bunthen" is the same type of speech level as krama inggil in Javanese. Suggestion is offered to the next researches in line with the topic of this research. Since the discussion of the relation of speech level and its influencing factors is not widely explained in this research, the following similar researches may widen the analysis on how each influencing factor impacts on the emergence of speech level in Maduranese language.

\section{REFERENCES}

Aslinda \& Syafyahya, L. (2007). Pengantar Sosiolinguistik. Bandung: Refika Aditama.

Chaer, A. \& Agustina. (1995). Sosiolinguistik: Perkenalan Awal. Jakarta: Rineka Cipta.

Effendy, Moh. Hafid. (2011). Tinjauan Deskriptif tentang Varian Bahasa Dialek Pamekasan. OKARA, 5(1), 63-74, DOI: http://dx.doi.org/10.19105/ojbs.v5i1.501.

Hudson. R.A. (1980). Sociolinguistics. London: Cambridge University Press.

Rahayu, Ika Mamik. (2013). Variasi Dialek Bahasa Jawa di Wilayah Kabupaten Ngawi: Kajian Dialektologi. Skriptorium, 1(2), 25-32.

Rohaniyah, Jaftiyatur. (2016). The Study of Madurese Social Dialect. Wacana Didaktika, 4(2), 102107, DOI: https://doi.org/10.31102/wacanadidaktika.4.2.102-107.

Sumarsono. (2010). Sosiolinguistik. Yogyakarta: Pustaka Pelajar. 